Article

\title{
Ecdysteroid Content and Therapeutic Activity in Elicited Spinach Accessions
}

\author{
Jonathan Gorelick ${ }^{1, *}$, Rona Hacohen Iraqi ${ }^{2,3}$ and Nirit Bernstein ${ }^{2, *}$ \\ 1 Eastern R\&D Center, Kiryat Arba 90100, Israel \\ 2 Institute of Soil, Water, and Environmental Sciences, Volcani Center, Rishon LeZion 7505101, Israel; \\ ronae3@gmail.com \\ 3 The Robert H. Smith Faculty of Agriculture, Food and Environment, Hebrew University of Jerusalem, \\ Rehovot 7612001, Israel \\ * Correspondence: jonathangorelick@gmail.com (J.G.); nirit@volcani.agri.gov.il (N.B.)
}

Received: 23 April 2020; Accepted: 3 June 2020; Published: 9 June 2020

check for updates

\begin{abstract}
While spinach is an established nutritionally important crop, its medicinal value is not as well known. Spinach is rich in ecdysteroids, insect hormone analogs with a number of medicinal properties including anti-oxidative, anti-inflammatory and even anabolic activity. However, the potential of spinach as a medicinal plant has not yet been developed. In this study, the ecdysteroid content of spinach was optimized to increase its therapeutic value. Spinach seeds from various sources were grown under controlled hydroponic conditions and analyzed for ecdysteroid content and related anabolic activity. Variations in ecdysteroid content and the related anabolic activity were observed among spinach accessions. A selected variety, Spinacia oleracea cv. Turkey, was exposed to various physical and chemical elicitors to increase and stabilize ecdysteroid content. A number of elicitors, including methyl salicylate and mechanical damage, significantly increased ecdysteroid content and anabolic activity $24 \mathrm{~h}$ after exposure. The effect was transient and disappeared $48 \mathrm{~h}$ thereafter. Further work is needed to identify the most suitable germplasm and elicitation conditions for optimal ecdysteroid content.
\end{abstract}

Keywords: spinach; ecdysteroid; elicitation; anabolic activity; protein synthesis

\section{Introduction}

\subsection{Spinach}

The recognized nutritional benefits of spinach are well known, rich in many vitamins and minerals [1]. While spinach is an established nutritionally important crop, the lesser known medicinal value hidden in spinach makes it a crop with significant market growth potential. Spinach was shown to possess anti-oxidative, anti-proliferative and anti-inflammatory properties [2]. A spinach enriched diet conferred a neuroprotective effect on aging rats, improving both their learning capacity and motor skills [3]. In addition to these medicinal properties which have largely been attributed to flavonoids, spinach contains another type of biologically active compound, ecdysteroids [4].

\subsection{Ecdysteroids}

Ecdysteroids, polyhydroxylated ketosteroids with long carbon side chains, are produced primarily in arthropods and plants, but are also present in fungi and even in marine sponges [5]. While 20-hydroxyecdysone (20HE) is the primary ecdysteroid found in arthropods, over 200 different ecdysteroids have been discovered in plants [6]. Although they are found throughout the living world, their discovery was only made within the last 60 years, and at first, their significance was not 
appreciated. In insects, ecdysteroids are involved in the molting process (ecdysis), while in plants there is evidence that they are involved in the plant defense response to insect herbivory [7]. The effects of ecdysteroids on mammalian cells were first documented in 1961 [8], and over time, the accumulation of data strongly supports their therapeutic activity [9]. Phytoecdysteroids are acknowledged today to possess a wide range of potentially therapeutic properties for humans, including anabolic [10], adaptogenic [11], hepatoprotective [12], spasmolytic [13] and anti-inflammatory activity [14].

Over 100 different preparations containing ecdysteroids can be found on the market containing either crude plant extracts or purified extracts with defined ecdysteroid content [15]. Most, which are sold over the Internet, are marketed to athletes, specifically body builders. Although mainly suggested to increase muscle, ecdysteroids are also sold to treat diabetes, to increase energy or as aphrodisiacs [16]. Some are even advertised for animals, including horses and dogs. In addition. ecdysteroids are also present in some cosmetics designed to improve moisture in the skin (Phenomen and Hydrastar from C. Dior).

\subsection{Ecdysteroids in Spinach}

Well known foods may contain lesser known therapeutic activities. Spinach (Spinacia oleracea) has been known to contain ecdysteroids, primarily 20HE, for some time [17], but is not widely used therapeutically as a source of ecdysteroids. The amounts present are considerably lower than in many of the other known ecdysteroid containing plants. However, of the major food crops, spinach contains the highest amounts of ecdysteroids, about $0.01 \%$ fresh weight [4]. Other related plants, including quinoa and asparagus, also contain significant levels as measured using High Pressure Liquid Chromatography (HPLC) and radioimmunoassay (RIA) [18]. Since spinach has a long history of use as a food crop and is generally recognized as safe, it is an ideal species to study the therapeutic activity of ecdysteroid enriched foods.

However, the ecdysteroid content found in spinach is quite variable [19]. This variation can be attributed to two main factors: genetic and environmental variability. The potential of genotype to affect ecdysteroid content was documented. Fifteen accessions of spinach grown under controlled conditions displayed significant differences in ecdysteroid content [20]. However, no wide-scale selection was undertaken for higher ecdysteroid producing lines. The other major factors involved in ecdysteroid content are the environmental conditions. Although many different variables may affect ecdysteroid content, its role in defense has focused research on defense related parameters primarily against insect pests [21]. Mechanical damage to the roots or leaves elicited increased ecdysteroid content [22]. Both exogenous 20HE and plant produced ecdysteroids produced abnormal molting, immobility, reduced invasion, impaired development and death in insects [21]. Production of 20HE in spinach is elicited by both mechanical wounding and insect feeding [21]. Phytoecdysteroids were found to protect spinach from plant-parasitic nematodes and may confer a mechanism for nematode resistance [7]. However, the response of spinach to different biotic or abiotic elicitors with regards to its therapeutic activity has not been characterized. Therefore, the goal of the present study was to characterize the ecdysteroid content and activity of a number of different spinach accessions grown under controlled conditions in order to evaluate the natural chemical variation present in varying spinach genotypes and their associated anabolic activity. Subsequently, the environmental role in chemical variation was evaluated by determining the effects of elicitation on ecdysteroid production. Elicitors induce physiological responses in the plant cells, which in turn often induce alterations to secondary metabolism. The effects of exposure of the plants to the elicitors on physiological parameters of the plant tissue was therefore tested to evaluate potential stress responses. The elicitors selected are known to stimulate the production of secondary metabolites in plants. Methyl salicylate (MS) and chitosan have been shown to be very effective at inducing the plant defense response $[23,24]$. MS is a natural plant derivative of salicylic acid implicated as an airborne signal involved with systemic acquired resistance [25]. Chitosan is a polysaccharide produced from the breakdown of the fungal cell wall component chitin. Treatment with chitosan mimics an attack from a fungal pathogen which activates the plant defense response [26]. Jasmonic acid and its related methyl ester, methyl jasmonate 
(MJ), play a key role in the signal transduction pathways which regulate the plant defense response and are involved in the production of various bioactive secondary metabolites [27]. Mechanical damage to either aerial or root tissue is known to activate the plant defense response and stimulate the production of secondary metabolites [28]. Membrane leakage and osmotic potential were measured as indicators of membrane damage and water relation status, respectively and concentration of photosynthetic pigments as the potential for carbon fixation.

\section{Results}

\subsection{Ecdysteroid Content}

The content of 20-HE was analyzed in 7 selected spinach types grown under controlled conditions (Figure 1a). Interestingly, there was a range of concentrations found in the leaf material from the various spinach sources. The accessions with the highest concentrations were PI604787 and P175312, containing an average of $17.3-\mu \mathrm{g} / \mathrm{g} 20 \mathrm{HE}$ and $16.8-\mu \mathrm{g} / \mathrm{g} 20 \mathrm{HE}$, respectively. These accessions also displayed a very large range of concentrations among the different plants from 10.1-25.8- $\mu \mathrm{g} / \mathrm{g} 20 \mathrm{HE}$ and $8.2-27.0-\mu \mathrm{g} / \mathrm{g} 20 \mathrm{HE}$, respectively. Spinach leaves from the Turkey variety contained less $20 \mathrm{HE}$ $(12.3 \mu \mathrm{g} / \mathrm{g})$ although this decrease was not significant. The lowest concentrations of $20 \mathrm{HE}$ were found in PI169673 and NLS6085, containing 10.27- $\mathrm{g} / \mathrm{g} 20 \mathrm{HE}$ and 9.3- $\mu \mathrm{g} / \mathrm{g} 20 \mathrm{HE}$, respectively. Interestingly, the range of concentrations of $20 \mathrm{HE}$ found in each spinach type also varied. The spinach types with higher 20HE content tended to have greater variation between plants while the types with lower concentrations had less variation in $20 \mathrm{HE}$ content.

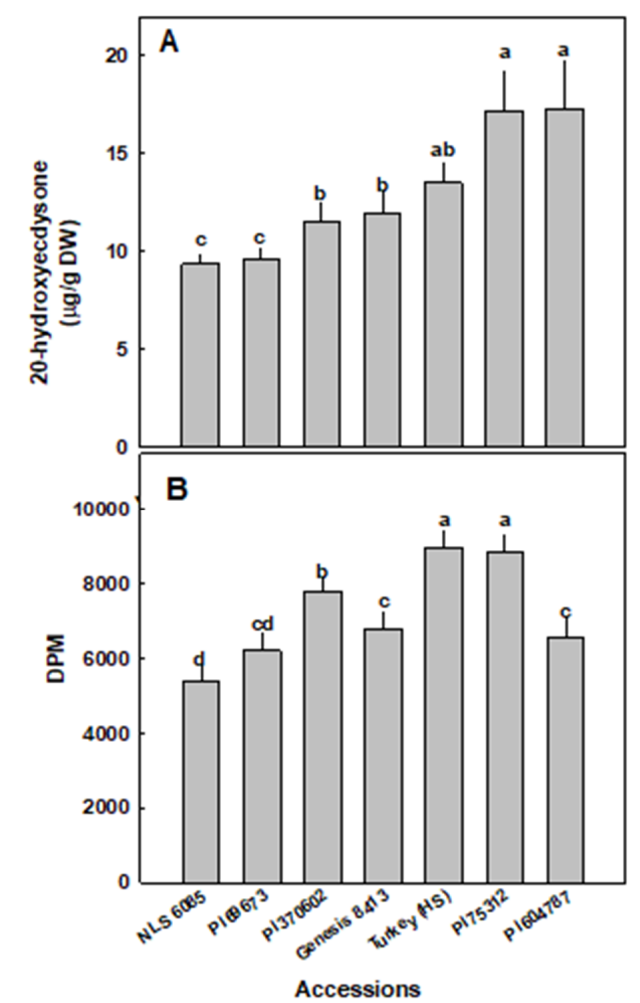

Figure 1. 20-Hydroxyecdysone content and anabolic activity in the leaves of 7 selected spinach accessions. (A) 20HE content was quantified using partially purified extracts of leaves from each of the 7 spinach accession analyzed via HPLC; (B) [3H] Leucine incorporation in L6 myotubes treated with different ecdysteroid-containing spinach extracts for $4 \mathrm{~h}$ was measured. Decays per minute (DPM) was normalized by total protein. The data represent the mean values \pm standard error of the mean (SEM) of four replicates. Different letters above the means represent significant difference based on Tukey's honestly significant difference (HSD) test at $\alpha=0.05$. 


\subsection{Anabolic Activity}

The anabolic activity associated with ecdysteroids was analyzed using a cellular model of protein synthesis in skeletal muscle cells. All spinach accessions tested significantly stimulated leucine incorporation compared to untreated cells $(4662 \pm 304$ Decays per minute (DPM)). The different spinach types produced varying increases in protein synthesis at least partially correlating with $20 \mathrm{HE}$ concentration (Figure 1B). PI175312, with a $20 \mathrm{HE}$ content of $16.8 \mu \mathrm{g} / \mathrm{g}$, produced the greatest increase in protein synthesis, while NLS6085, with a 20HE content of $9.3 \mu \mathrm{g} / \mathrm{g}$ stimulated the smallest increase. Interestingly, the effects on protein synthesis could only partially be correlated to ecdysteroid content. The highest increase in protein synthesis was produced by the Turkey variety, even though its $20 \mathrm{HE}$ content was lower than PI604787, which contained the highest content of 20HE. While Genesis 8413 and PI370602 contained similar 20HE content (11.9-11.5 $\mu \mathrm{g} / \mathrm{g})$ PI370602 increased protein synthesis significantly more than Genesis 8413 . PI6973, which contained slightly less $20 \mathrm{HE}(10.3 \mu \mathrm{g} / \mathrm{g})$ generated a slightly less increase, although the difference was not statistically significant. Surprisingly, PI604787, which contained comparable 20HE with PI75312, stimulated a significantly smaller increase in protein synthesis.

\subsection{Elicitation on Ecdysteroid Content}

After verifying the ecdysteroid content and the associated biologic activity, elicitation was utilized to increase and stabilize the ecdysteroid content. Because of its potent activity on protein synthesis-as well as the fact that it is a modern developed variety, possessing many agriculturally desirable attributes in addition to high ecdysteroid content-the Turkey variety was selected for use in elicitation experiments.

All elicitors studied produced a change in 20HE content (Figure 2A). The greatest increase in $20 \mathrm{HE}$ content was observed in plants treated with MS or root or leaf-wounding. Twenty-four hours after initiation of the MS treatments, a $200 \%$ increase in 20HE from 8.3 to $24.1-24.7 \mu \mathrm{g} / \mathrm{g}$ was observed. MJ treatment increased $20 \mathrm{HE}$ content by $\sim 100 \%$ reaching $17.2 \mu \mathrm{g} / \mathrm{g}$. The observed increase was transient. After $72 \mathrm{~h}$, not only did the previously observed increase in 20HE content dissipate, but it even dropped to about half of the content found in the control untreated plants. Surprisingly, chitosan treatment did not significantly increase $20 \mathrm{HE}$ content.

\subsection{Elicitation and Anabolic Activity}

In order to correlate the changes in ecdysteroid content observed in elicited spinach with the associated therapeutic activity, effects on protein synthesis in skeletal muscle were studied. Skeletal muscle cells (L6) were treated with extracts from leaves of spinach plants treated with various elicitors and the incorporation of tritiated leucine into protein was quantified (Figure 2B).

Supporting our previous findings, leaves from untreated spinach leaves significantly increased protein synthesis in skeletal muscle cells compared with cells which received the vehicle $(6485 \pm 476.6 \mathrm{DPM})$. Furthermore, $24 \mathrm{~h}$ after elicitation, plants stimulated a significantly larger increase in protein synthesis than that produced by untreated plants. The largest increase in protein synthesis was produced by plants treated with wounding of leaf or roots as well as MS. A smaller yet significant increase in protein synthesis was observed in MJ treated plants compared with non-elicited plants. This increase dissipated after $72 \mathrm{~h}$, reverting to activity similar to the protein synthesis observed in non-elicited plants. In the case of root-wounding, after $72 \mathrm{~h}$ the stimulated protein synthesis was actually lower, although not statistically significant, than in non-elicited plants. These changes in anabolic activity, both the increase after $24 \mathrm{~h}$ and the subsequent decrease after $72 \mathrm{~h}$, parallel the previously observed increases in $20 \mathrm{HE}$ content. The increase in protein synthesis from chitosan treated plants was similar to non-elicited plants. 


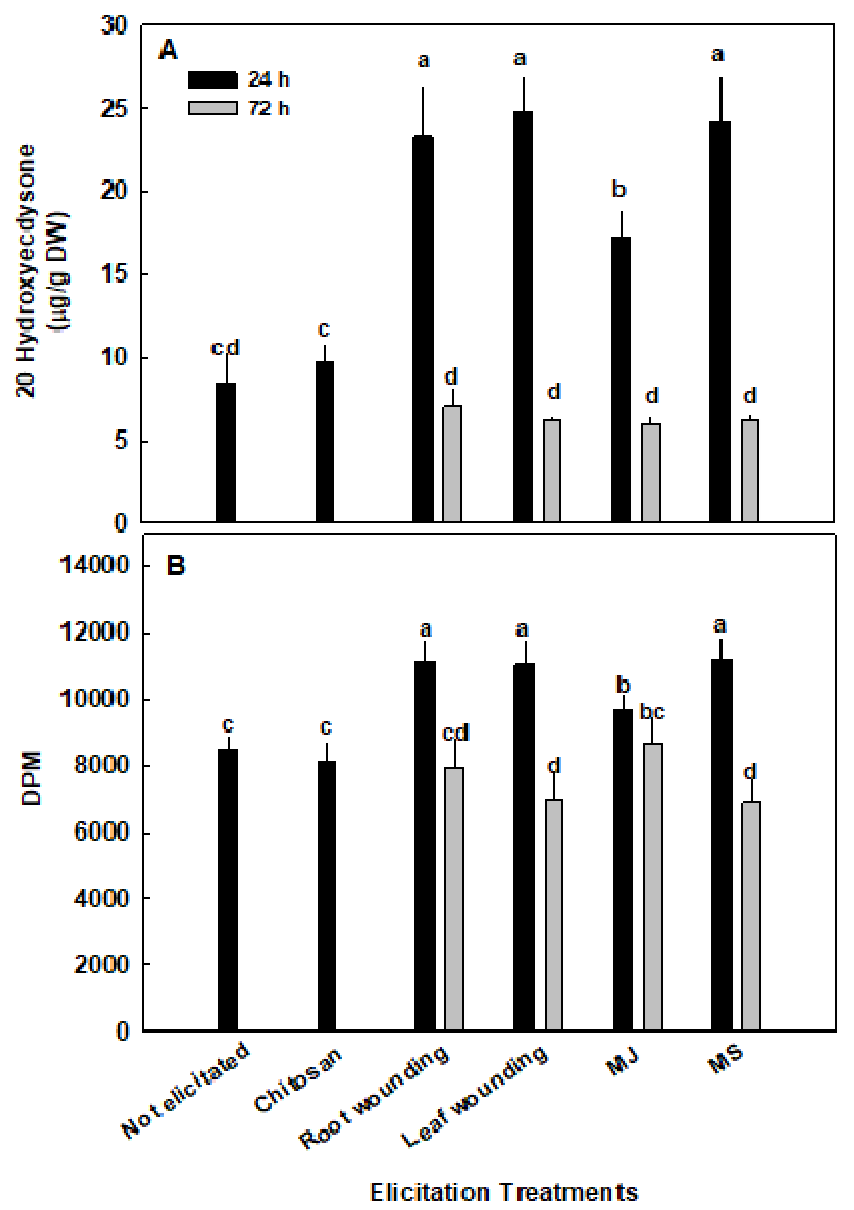

Figure 2. 20HE content and anabolic activity in elicited Turkey variety spinach plant leaves. (A) $20 \mathrm{HE}$ content was quantified using partially purified extracts of leaves from elicited spinach analyzed via HPLC; (B) [3H] Leucine incorporation in L6 myotubes treated with elicited spinach extracts for $4 \mathrm{~h}$ was measured. Decays per minute (DPM) was normalized by total protein. The data represent the mean values \pm standard error of the mean (SEM) of four replicates. Different letters above the means represent significant difference based on Tukey's honestly significant difference (HSD) test at $\alpha=0.05$.

\subsection{Physiological Response to Elicitation}

Evaluating changes in stress-related physiological parameters was aimed at identifying plant characteristics that correlate with stimulation of increased bioactivity. The elicitation treatments did not affect membrane leakage from the leaf tissue (Figure 3A), nor the osmotic potential of the tissue sap (Figure 3B). While many changes in secondary metabolite production are result of the physiological stress which may be induced in the plant by the elicitors, this does seem to be the case in the present study. The lack of change in membrane leakage or osmotic potential suggest that the elicitation treatments which increased ecdysteroid content after $24 \mathrm{~h}$ did not produce significant physiological stress in the plants.

Almost no changes in pigmentation were observed following elicitation treatments (Figure 4). Only chitosan treatment significantly reduced both chlorophyll a and b while increasing carotenoid levels. This is surprising as most studies using chitosan report an increase in chlorophyll content $[29,30]$. While other elicitors like salicylic acid have been observed to lower chlorophyll content [31], the observed chlorophyll lowering effects of chitosan have never been reported. Surprisingly, while salicylic acid treatment has been shown to increase carotenoid content in plants [32], the effects of chitosan on carotenoid levels have not been documented. 


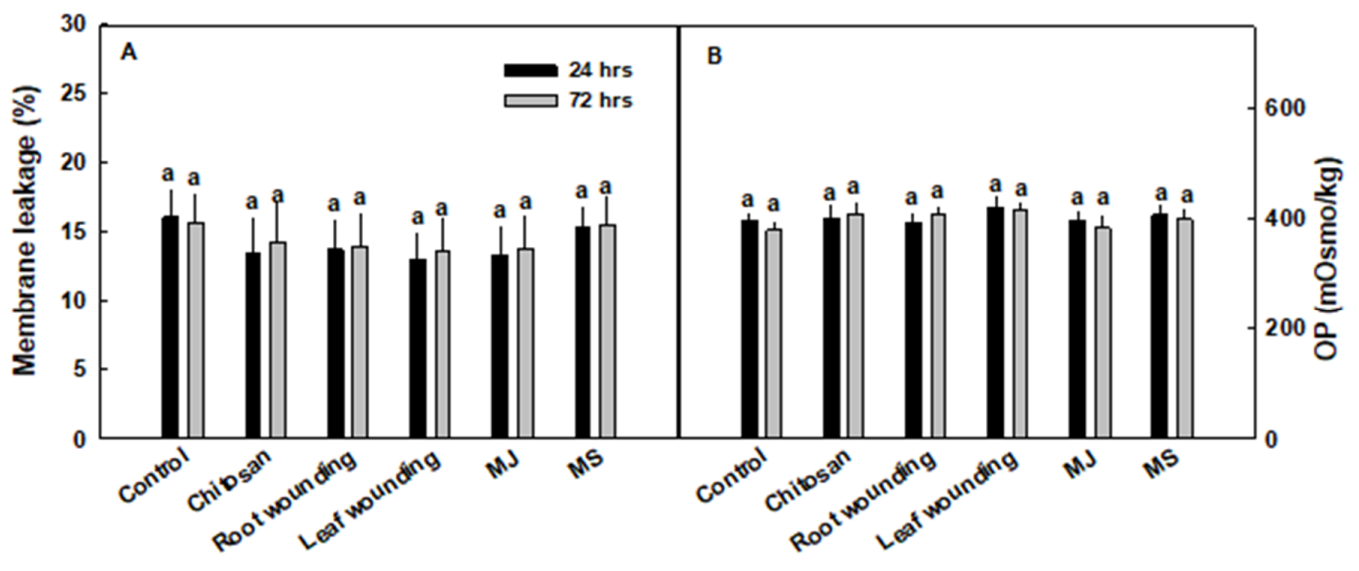

Elicitation Treatment

Elicitation Treatment

Figure 3. (A) Membrane leakage and (B) osmotic potential in elicited Turkey variety spinach plant leaves. The data represent means \pm SE $(n=5)$. Different letters above the means represent significant difference based on Tukey's HSD test at $\alpha=0.05$.

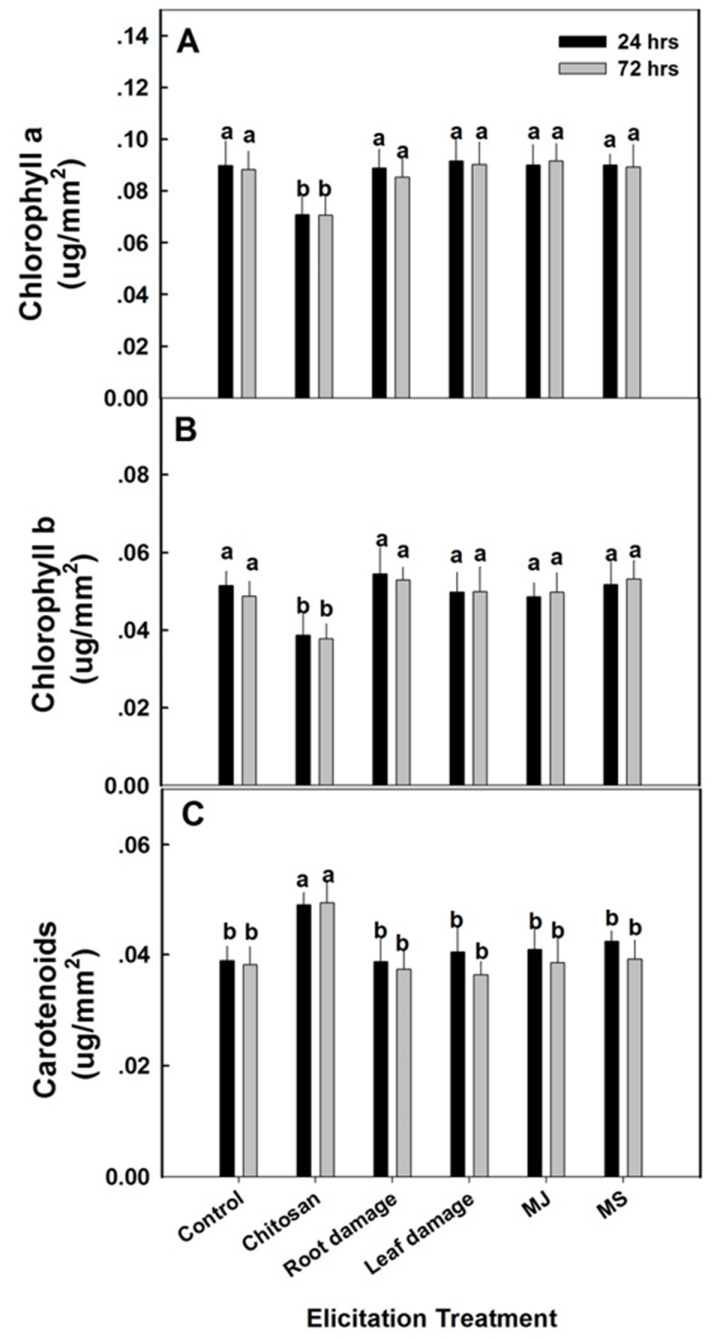

Figure 4. Photosynthetic pigments in elicited Turkey variety spinach leaves. Measurements of (A) chlorophyll a, (B) chlorophyll b, and (C) carotenoids were conducted $24 \mathrm{~h}$ after the initiation of the elicitation treatments $(24 \mathrm{~h})$ and $48 \mathrm{~h}$ thereafter $(72 \mathrm{~h})$. Methyl salicylate (MS), methyl jasmonate (MJ) and chitosan were removed after $24 \mathrm{~h}$ exposure. The data represent means \pm SE $(n=5)$. Different letters above the means represent significant difference based on Tukey's HSD test at $\alpha=0.05$. 


\section{Discussion}

A range of $20 \mathrm{HE}$ concentrations was observed in the various spinach material with sources with higher $20 \mathrm{HE}$ content possessing greater interplant variation. This increased chemical variability among different plant populations have been previous documented for a number of species [33-35]. These findings suggest that the level of variation in ecdysteroid content within a single population may vary depending on the germplasm. In addition. different levels of genetic heterogeneity may exist among the different accessions studied.

The anabolic activity associated with ecdysteroids was confirmed with the different spinach types producing varying increases in protein synthesis. Interestingly, the anabolic activity did not completely correlate with ecdysteroid content. It is quite plausible that other non-ecdysteroid compounds are present in spinach with anabolic activity [2]. In addition. there may also be compounds which inhibit anabolic activity. Further work is needed to better characterize the various chemical factors influencing spinach's anabolic activity.

Overall, we have confirmed that the 20HE content in spinach varies greatly among different germplasm. Of course, a larger survey is needed to adequately evaluate the 20HE variation among spinach worldwide. The ability of elicitation to modulate 20HE content was also observed, supporting previous findings [22]. While the ability to significantly improve the ecdysteroid content in spinach has been supported, there is still much work ahead. The development of a spinach based ecdysteroid-containing nutraceutical demands additional biotechnological research. Optimization of ecdysteroid content must be monitored using sophisticated chemical analysis as well as cell based biologic assays in order to assure the therapeutic activity.

\section{Materials and Methods}

\subsection{Plant Material}

Spinach seeds, Spinacia oleracea cv. Turkey and cv. Sabanach (Genesis 8413) were obtained from Hishtil (Nehalim, Israel) and Genesis Seeds, Ltd. (Rehovot, Israel) accordingly. Spinach seeds of NSL 6085 (U.S.), PI 169673 (Turkey), PI 175312 (India), PI 370602 (Macedonia), PI604787 (Afghanistan) were obtained from the U.S. Department of Agriculture's Agricultural Resource Service, Germplasm Resources Information Network (USDA-ARS GRIN). Accessions were selected from the USDA seed bank based on reported insect resistance with the likelihood that their ecdysteroid content may be naturally higher [36].

\subsection{Growing Conditions}

All plants were germinated from seed at a commercial nursery (Hishtil, Nehalim, Israel) and after 24 days, transferred to aerated one-quarter strength modified Hoagland hydroponic solution [37], 5 plants each into $14 \mathrm{~L}$ containers in a climate controlled greenhouse maintained at $21-30{ }^{\circ} \mathrm{C}$ at the Volcani Institute (Rishon Le-Ziyon, Israel) [38]. Iron (Fe-EDTA) was added to the growing media to a final concentration of $50-\mu \mathrm{M}$ and sodium (as $\mathrm{NaCl}$ ) to a final concentration of $1 \mathrm{mM}$. The $\mathrm{pH}$ of the solution was maintained at 5.7 through daily adjustment with $\mathrm{KOH}$. The hydroponic solution was replaced weekly.

\subsection{Elicitation}

Elicitors including methyl salicylate (MS), methyl jasmonate (MJ) and chitosan-as well as leaf- or root-wounding - were utilized to stimulate the plant stress response to increase the 20HE content and anabolic activity of spinach based on [39] with minor modifications.

Spinach seedlings grown under the previously described hydroponic conditions were divided using a random block design into five replicated hydroponic containers of five plants each per treatment ( 25 plants per elicitation treatment). Selected elicitor concentrations were determined based on preliminary studies (results not shown). The three chemical elicitors (390 $\mu \mathrm{g} / \mathrm{L} \mathrm{MS}, 390 \mu \mathrm{g} / \mathrm{L} \mathrm{MJ}$, 
$150 \mathrm{mg} / \mathrm{L}$ chitosan) were added to the hydroponic nutrient media. For plants sampled after $72 \mathrm{~h}$, the $24 \mathrm{~h}$ treatment with the chemical elicitors was followed by replacement with the original hydroponic growing solution for an additional $48 \mathrm{~h}$. Physical elicitation was produced using scissors to generate slight cuts in the upper leaves for leaf-wounding. Root-wounding was produced by gentle pruning of the root tips. At the conclusion of the 24 or $72 \mathrm{~h}$ periods, plants were harvested, and samples analyzed for physiological response, chemical composition and bioactivity. The physiological response of elicited plants was compared to control plants by measuring the membrane leakage and osmotic potential of leaf sap [40].

\subsection{Membrane Leakage}

Measurement of membrane leakage —an indicator of stress-related injury [41]—-were studied as previously described with minor changes [42]. After leaf segments were shaken in $30 \mathrm{~mL}$ of double-distilled water for $24 \mathrm{~h}$, electrical conductivity (EC) was measured using a conductivity meter (CyberScan CON 1500; Eutech Instruments, Ayer Rajan Crescent, Singapore). Leaf pieces were subsequently autoclaved and shaken for $1 \mathrm{~h}$. Conductivity measurements were repeated and the ratio between the first and the second conductivity measurements were used to calculate membrane leakage, presented as percentages. Five replicated leaves were averaged to generate the final results.

\subsection{Osmotic Potential}

For osmotic potential measurements, leaf tissue from the center of the youngest mature leaf on the plant was sampled—and following washing with deionized water-was blotted dry and frozen in liquid nitrogen in $1.5 \mathrm{~mL}$ micro-tubes and stored at $5{ }^{\circ} \mathrm{C}$ for further analyses. The frozen tissue was crushed with a glass rod, the bottom of the tubes pin-pricked, set inside another $1.5 \mathrm{~mL}$ tube and centrifuged in a refrigerated centrifuge (Sigma Laboratory Centrifuges, Osterode am Harz, Germany) at $5{ }^{\circ} \mathrm{C}$ at $10,000 \mathrm{rpm}$ for $4 \mathrm{~min}$. The fluid collected in the lower micro-tube $(100 \mathrm{~L})$ was used for measurement of osmotic potential using a cryoscopic micro-osmometer (Osmette; Precision Systems, Natick, MA, USA), measuring the sap freezing point. Results are presented in $\mathrm{mOsm}{ }^{*} \mathrm{~kg} \mathrm{H}_{2} \mathrm{O}^{-1}$. Five replicates were analyzed from each treatment.

\subsection{Chlorophyll and Carotenoids Content}

The youngest mature leaf from each plant was separated and rapidly washed in distilled water. A tissue segment of $20 \times 20 \mathrm{~mm}$ removed from halfway along the length of the leaf was used for analyzing chlorophyll $\mathrm{a}$ and $\mathrm{b}$ and carotenoid content. Discs of $6 \mathrm{~mm}$ diameter, cut from leaf sections avoiding the mid-rib, were placed in $80 \%(v / v)$ ethanol and heated for $30 \mathrm{~min}$ at $92{ }^{\circ} \mathrm{C}$. After boiling, the soluble extract was collected in $2 \mathrm{~mL}$ micro tubes. Extraction was repeated with the remaining tissue at room temperature for $15 \mathrm{~min}$ and the combined extracts was vortexed. Absorbance was measured at 663, 646 and $470 \mathrm{~nm}$ using a Genesys 10 UV Scanning spectrophotometer (Thermo Scientific, Madison, WI, USA). Chlorophyll a and $\mathrm{b}$ and carotenoid content was calculated based on [43].

\subsection{Ecdysteroid Extraction and Quantification}

The youngest fully mature leaf on the plants was sampled for analysis of ecdysteroid content and immediately frozen and stored at $-80^{\circ} \mathrm{C}$. In experiments were the concentration was also analyzed $48 \mathrm{~h}$ after the removal of the elicitor, i.e., $72 \mathrm{~h}$ after the initiation of the elicitation treatment, the same leaf was sampled for the analyses. The collected samples were ground and extracted in methanol for $24 \mathrm{~h}$. The supernatant was filtered and evaporated to dryness under reduced pressure. Samples were resuspended in $70 \%$ methanol in water and then partitioned against hexane. The aqueous fraction was evaporated, resuspended in water, and partitioned against butanol. The butanol fraction was evaporated, resuspended in methanol, filtered $(0.45 \mu \mathrm{m})$, and analyzed using HPLC (Waters LC Module 1 with 996 PDA detector, Milford, MA, USA). Samples $(20 \mu \mathrm{L})$ were injected onto a ODS column (Phenomenex Luna $(4.6 \mathrm{~mm} \bullet 25 \mathrm{~cm}, 5 \mu \mathrm{m})$, Torrance, CA, USA) using an isocratic elution with 
a mobile phased of water/methanol (40:60) and a flow of $1.0 \mathrm{~mL} / \mathrm{min}$. Quantification was performed using standard curves generated with $>93 \%$ purified 20-hydroxyecdysone (1-1000 ng) (Sigma-Aldrich, St. Louis, MO, USA).

\subsection{Protein Synthesis Activity}

The effects of partially purified spinach extracts on total protein synthesis in skeletal myotubes were studied based on [10]. Briefly, L6 cells were washed with serum-free Dulbecco's modified Eagle's medium (DMEM) and treated with purified spinach extracts, insulin like growth factor 1 (IGF-1) or vehicle, $0.1 \%$ ethanol, four wells per treatment. Samples were added to serum-free medium containing $5-\mu \mathrm{Ci} / \mathrm{mL}[3 \mathrm{H}]$ Leucine. Cells were incubated for $4 \mathrm{~h}$ before protein measurement. Following treatment, cells were washed with cold phosphate-buffered saline (PBS), followed by the addition of $5 \%$ trichloroacetic acid (TCA) to precipitate protein. After $30 \mathrm{~min}$ at $4{ }^{\circ} \mathrm{C}$, the TCA was removed, and the precipitate was dissolved in $0.5-\mathrm{M} \mathrm{NaOH}(500 \mu \mathrm{L})$. The dissolved precipitate $(400 \mu \mathrm{L})$ was added to scintillation vials with $5 \mathrm{~mL}$ of scintillation fluid (Ready Safe, Beckman Coulter, Fullerton, CA, USA). Decays per minute (DPM) were measured in a liquid scintillation counter (LS 6500, Beckman Coulter, Fullerton, CA, USA). Total protein was quantified using the bicinchoninic acid (BCA) method following the manufacturer's instructions (Pierce, Rockford, IL, USA). Data were expressed as DPM per milligram of total protein. Each experiment was performed in triplicate. The results were expressed as mean \pm SEM. Statistical significance was determined using one-way ANOVA and Tukey's HSD for comparison of means.

Author Contributions: Conceptualization, J.G., N.B. and R.H.I.; methodology, J.G., N.B. and R.H.I.; software, J.G., N.B. and R.H.I.; investigation, J.G., N.B. and R.H.I.; resources, J.G., N.B. and R.H.I.; writing-original draft preparation, J.G., N.B. and R.H.I.; writing-review and editing, J.G., N.B. and R.H.I. All authors have read and agreed to the published version of the manuscript.

Funding: This work was carried out with support from the Israeli Ministry of Science, Technology and Space as well as the Israeli Ministry of Agriculture.

Acknowledgments: We thank Shani Shoshan for expert technical assistance.

Conflicts of Interest: The authors declare no conflicts of interest.

\section{References}

1. Roberts, J.L.; Moreau, R. Functional properties of spinach (Spinacia oleracea L.) phytochemicals and bioactives. Food Funct. 2016, 7, 3337-3353. [CrossRef] [PubMed]

2. Lomnitski, L.; Bergman, M.; Nyska, A.; Ben-Shaul, V.; Grossman, S. Composition, Efficacy, and Safety of Spinach Extracts. Nutr. Cancer 2003. [CrossRef] [PubMed]

3. Cartford, M.C.; Gemma, C.; Bickford, P.C. Eighteen-month-old Fischer 344 rats fed a spinach-enriched diet show improved delay classical eyeblink conditioning and reduced expression of tumor necrosis factor $\alpha$ $(\mathrm{TNF} \alpha)$ and TNF $\beta$ in the cerebellum. J. Neurosci. 2002. [CrossRef]

4. Grebenok, R.J.; Ripa, P.V.; Adler, J.H. Occurrence and levels of ecdysteroids in spinach. Lipids 1991. [CrossRef]

5. Lafont, R.; Koolman, J. Diversity of Ecdysteroids in Animal Species. In Ecdysone: Structures and Functions; Springer: Berlin, Germany, 2009.

6. Dinan, L.; Savchenko, T.; Whiting, P. On the distribution of phytoecdysteroids in plants. Cell. Mol. Life Sci. 2001. [CrossRef]

7. Soriano, I.R.; Riley, I.T.; Potter, M.J.; Bowers, W.S. Phytoecdysteroids: A novel defense against plant-parasitic nematodes. J. Chem. Ecol. 2004. [CrossRef]

8. Couderc, J.-L. Ecdysone: From Metabolism to Regulation of Gene Expression. Papers from the Seventh Ecdysone Workshop, Edinburgh, UK, March 31-April 3, 1985. Mary Bownes. Q. Rev. Biol. 1987. [CrossRef]

9. Vanyolos, A.; Bathori, M. New Perspectives in the Analysis of Ecdysteroids: A Promising Group of Biologically Active Compounds. Curr. Pharm. Anal. 2008. [CrossRef]

10. Gorelick-Feldman, J.; MacLean, D.; Ilic, N.; Poulev, A.; Lila, M.A.; Cheng, D.; Raskin, I. Phytoecdysteroids increase protein synthesis in skeletal muscle cells. J. Agric. Food Chem. 2008. [CrossRef] 
11. Lafont, R.; Dinan, L. Practical uses for ecdysteroids in mammals including humans: And update. J. Insect Sci. 2003. [CrossRef]

12. Bajguz, A.; Bakała, I.; Talarek, M. Ecdysteroids in plants and their pharmacological effects in vertebrates and humans. In Studies in Natural Products Chemistry; Elsevier: Amsterdam, The Netherlands, 2015.

13. Tavares, M.C.H.; Yariwake Vilegas, J.H.; Lanças, F.M. Phytoecdysteroid profiles in seeds of Sida spp. (Malvaceae). Phytochem. Anal. 2001. [CrossRef]

14. Sarpong, F.M.; Armah, F.A.; Amponsah, I.K.; Atchoglo, P.K. Antinociceptive ecdysteroids and other constituents of palisota hirsuta k. schum (commelinaceae). J. Appl. Pharm. Sci. 2016. [CrossRef]

15. Hunyadi, A.; Herke, I.; Lengyel, K.; Báthori, M.; Kele, Z.; Simon, A.; Tóth, G.; Szendrei, K. Ecdysteroid-containing food supplements from Cyanotis arachnoidea on the European market: Evidence for spinach product counterfeiting. Sci. Rep. 2016. [CrossRef] [PubMed]

16. Available online: www.ecdybase.org (accessed on 9 March 2020).

17. Bathori, M.; Mathe, I., Jr.; Solymosi, P.; Szendrei, K. Phytoecdysteroids in some species of Caryophyllaceae and Chenopodiaceae. Acta Bot. Hung. 1987, 33, 377-385.

18. Dinan, L.; Savchenko, T.; Whiting, P. Phytoecdysteroids in the genus Asparagus (Asparagaceae). Phytochemistry 2001. [CrossRef]

19. Bakrim, A.; Maria, A.; Sayah, F.; Lafont, R.; Takvorian, N. Ecdysteroids in spinach (Spinacia oleracea L.): Biosynthesis, transport and regulation of levels. Plant Physiol. Biochem. 2008. [CrossRef] [PubMed]

20. Cheng, D.M.; Yousef, G.G.; Lila, M.A. Variation in phytoecdysteroid accumulation in seeds and shoots of Spinacia oleracea L. accessions. HortScience 2010, 45, 1634-1638. [CrossRef]

21. Schmelz, E.A.; Grebenok, R.J.; Ohnmeiss, T.E.; Bowers, W.S. Interactions between Spinacia oleracea and Bradysia impatiens: A role for phytoecdysteroids. Arch. Insect Biochem. Physiol. 2002. [CrossRef]

22. Schmelz, E.A.; Grebenok, R.J.; Galbraith, D.W.; Bowers, W.S. Damage-induced accumulation of phytoecdysteroids in spinach: A rapid root response involving the octadecanoic acid pathway. J. Chem. Ecol. 1998. [CrossRef]

23. Ament, K.; Krasikov, V.; Allmann, S.; Rep, M.; Takken, F.L.W.; Schuurink, R.C. Methyl salicylate production in tomato affects biotic interactions. Plant J. 2010. [CrossRef]

24. El Hadrami, A.; Adam, L.R.; El Hadrami, I.; Daayf, F. Chitosan in plant protection. Mar. Drugs 2010, 8, 968-987. [CrossRef] [PubMed]

25. Shah, J.; Chaturvedi, R.; Chowdhury, Z.; Venables, B.; Petros, R.A. Signaling by small metabolites in systemic acquired resistance. Plant J. 2014. [CrossRef] [PubMed]

26. Hadwiger, L.A. Plant science review: Multiple effects of chitosan on plant systems: Solid science or hype. Plant Sci. 2013, 208, 42-49. [CrossRef] [PubMed]

27. Gorelick, J.; Bernstein, N. Elicitation: An underutilized tool in the development of medicinal plants as a source of therapeutic secondary metabolites. Adv. Agron. 2014. [CrossRef]

28. Jacobo-Velázquez, D.A.; González-Aguëro, M.; Cisneros-Zevallos, L. Cross-talk between signaling pathways: The link between plant secondary metabolite production and wounding stress response. Sci. Rep. 2015. [CrossRef]

29. Choudhary, R.C.; Kumaraswamy, R.V.; Kumari, S.; Sharma, S.S.; Pal, A.; Raliya, R.; Biswas, P.; Saharan, V. $\mathrm{Cu}$-chitosan nanoparticle boost defense responses and plant growth in maize (Zea mays L.). Sci. Rep. 2017, 7, 9754. [CrossRef]

30. Abu-Muriefah, S.S. Effect of chitosan on common bean (Phaseolus vulgaris L.) plants grown under water stress conditions. Int. Res. J. Agric. Sci. Soil Sci. 2013, 3, 192-199.

31. Moharekar, S.T.; Lokhande, S.D.; Hara, T.; Tanaka, R.; Tanaka, A.; Chavan, P.D. Effect of salicylic acid on chlorophyll and carotenoid contents of wheat and moong seedlings. Photosynthetica 2003. [CrossRef]

32. Ahmed, F.; Fanning, K.; Netzel, M.; Schenk, P.M. Induced carotenoid accumulation in Dunaliella salina and Tetraselmis suecica by plant hormones and UV-C radiation. Appl. Microbiol. Biotechnol. 2015. [CrossRef]

33. Pedneault, K.; Léonhart, S.; Gosselin, A.; Angers, P.; Papadopoulos, A.P.; Dorais, M. Variations in concentration of active compounds in four hydroponically- and field-grown medicinal plant species. In IV International ISHS Symposium on Artificial Lighting; International Society for Horticultural Science (ISHS): Leuven, Belgium, 2002; Volume 580, pp. 255-262.

34. Gobbo-Neto, L.; Lopes, N.P. Medicinal plants: Factors of influence on the content of secondary metabolites | Plantas medicinais: Fatores de influência no conteúdo de metabólitos secundários. Quim. Nova 2007, 30, S0100-S40422007000200026. [CrossRef] 
35. Towler, M.J.; Weathers, P.J. Variations in key artemisinic and other metabolites throughout plant development in Artemisia annua L. for potential therapeutic use. Ind. Crops Prod. 2015, 67, 185-191. [CrossRef] [PubMed]

36. Mou, B. Leafminer resistance in spinach. HortScience 2008, 43, 1716-1719. [CrossRef]

37. Bernstein, N.; Lauchli, A.; Silk, K. Kinematics and Dynamics of Sorghum ( Sorghum bicolor 1.) Leaf Development at Various Na/Ca Salinities. Plant Physiol. 1993. [CrossRef] [PubMed]

38. Bernstein, N.; Kravchik, M.; Dudai, N. Salinity-induced changes in essential oil, pigments and salts accumulation in sweet basil (Ocimum basilicum) in relation to alterations of morphological development. Ann. Appl. Biol. 2010. [CrossRef]

39. Gorelick, J.; Rosenberg, R.; Smotrich, A.; Hanuš, L.; Bernstein, N. Hypoglycemic activity of withanolides and elicitated Withania somnifera. Phytochemistry 2015, 116, 283-289. [CrossRef]

40. Bernstein, N.; Shoresh, M.; Xu, Y.; Huang, B. Involvement of the plant antioxidative response in the differential growth sensitivity to salinity of leaves vs roots during cell development. Free Radic. Biol. Med. 2010. [CrossRef]

41. Lu, S.; Wang, Z.; Niu, Y.; Guo, Z.; Huang, B. Antioxidant responses of radiation-induced dwarf mutants of bermudagrass to drought stress. J. Am. Soc. Hortic. Sci. 2008. [CrossRef]

42. Shoresh, M.; Spivak, M.; Bernstein, N. Involvement of calcium-mediated effects on ROS metabolism in the regulation of growth improvement under salinity. Free Radic. Biol. Med. 2011. [CrossRef]

43. Lichtenthaler, H.; Wellburn, A. Determinations of total carotenoids and chlorophylls b of leaf extracts in different solvents. Biochem. Soc. Trans. 1983. [CrossRef]

(C) 2020 by the authors. Licensee MDPI, Basel, Switzerland. This article is an open access article distributed under the terms and conditions of the Creative Commons Attribution (CC BY) license (http://creativecommons.org/licenses/by/4.0/). 